\title{
Ground Zero, an American Origin
}

Mary Caputi

Poroi, 2, 1, August, 2003

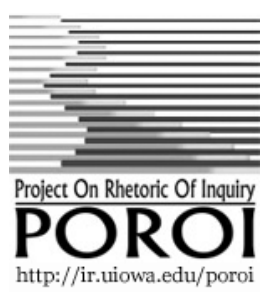

When I have seen by Time's fell hand defaced The rich proud cost of outworn buried age, When sometimes lofty towers I see down-razed, And brass eternal slave to mortal rage.... . Ruin hath taught me thus to ruminate, That Time will come and take my love away. This thought is as a death, and cannot choose But weep to have that which it fears to lose. -William Shakespeare, "Sonnet 64"

1 The tragedy of September 11, 2001 elicited a tremendous emotional response from Americans. It produced an outpouring of grief, outrage, bewilderment, and renewed patriotic fervor. It also brought out feelings of compassion and camaraderie among New Yorkers, in particular, as people from all walks of life pulled together in a collective effort to help the city recover. For most people, the legacy of 9/11 is likely to remain emotional. Yet Shakespeare's sonnet show how emotional responses to ruin can inspire ruminations about devastation. Ruin teaches the poet to reflect on visions of collapsed towers. Shakespeare finds in vistas of fallen towers a sense of sadness but also a moment of recognition, an intellectual discovery. So may we.

2 This discovery arises from allegorical dimensions of the rubble. Indeed the surpluses of meaning in the felled structures make them apt sites for scrutiny, as the remains point to realities beyond our literal worlds. An abundance of signifying potential in the buildings' ruins speak of more than architectural decay. In the ruins, the poet encounters allusions to the brevity of time and the fleeting quality of human life. Especially the rubble induces the poet to think differently about love. It provides a painful reminder that human bonds are ephemeral. As history runs its course, they, too, are fragmented by "Time's fell hand."

3 Do similarly stirring or instructive insights for Americans come from the devastation of the Twin Towers? Do our images and memories of the ruined World Trade Center -- the heap of rubble, debris, destroyed infrastructure, burning fires, noxious smoke, smothering ash -- contain allegorical dimensions that might encourage Americans not only to react 
emotionally to 9/ 11 but also to learn from it? The invitation in Shakespeare's sonnet is to dwell on lasting images of the WTC's ruin. Americans have these aplenty, but how might we reflect on them?

4 The rubble of the Twin Towers has been heavy with political significance. Hence it is less to Shakespeare's poetry of love and death that we might turn for an analytical framework to ponder the 9/11 images of remains. We might find more inspiration in Walter Benjamin's notion of ruins as emblems for discarded, hollowed-out lives in modern conditions. Benjamin's theory of allegory, developed especially in his The Origins of German Tragic Drama ( Ursprung des Deutsches Trauerspiel), evokes diverse meanings of Ground Zero in New York City that can spur Americans to ruminate on the ruins of 9/11 and learn from the antiAmerican aggression of that day. ${ }^{1}$ As allegorical emblems, the ruins of the WTC can teach us to think differently about how America became so hated by some and how that hatred might stop.

\section{Manhattan's Lofty Towers “Down-Razed”}

5 Before turning to Benjamin's theory of allegory as it applies to Ground Zero, let us recall the horrific images of that site that became emblazoned in our minds. The sight of an airplane crashing into each of the Twin Towers may well be the most familiar image for most Americans of the terrorist attacks. Such images appeared on numerous magazine covers, and videotaped versions of the crashes replayed incessantly on television. Nevertheless a reading of Benjamin suggests that the immense pile of rubble from the collapse of the towers can make a more lasting and instructive imprint on the minds of Americans. Whereas the crashing airplanes recollect the horror of the attacks themselves, the enduring visions of abundant ruins evoke questions of how we can survive and respond to anti-American actions. The devastation wrought by the crashes -- the sight of "lofty towers . . . down-razed" and the rubble they produced - provoke questions of what 9/11 means to America. How have we found ourselves in the ruins? How do we take them into our communities? How will we move beyond them? America has been the new world, not a land with room for ruins. To ponder the WTC rubble is to ask whether our culture can survive in the face of terror directed against it and what Americans can learn from grievances of others.

6 Many photographs of Ground Zero feature police officers and fire fighters. In a haze of smoke and ash, they search for survivors, remains, meanings. They work to impose organization through bewildering tasks of putting out fires, sorting through debris, and cleaning up the rubble. Like shadows cast over these pictures are memories of the two signature towers standing tall on the skyline of New York: commercial capital of the globe, home to 
the United Nations, gateway for immigration, the big city for Americans. Pictures of Ground Zero often show the remaining infrastructure of the WTC encircled by piles of crumbled cement, broken plaster, splintered wood, fragmented plumbing, and demolished furniture. There are assortments of office supplies and personal items that had belonged to the victims. These photographs can make human efforts seem small in comparison to the immensity of the ruined buildings and, perhaps, the hatred that struck them down. Ironically the piles of rubble make clear how carefully these attacks had been planned and how awful was the animosity that drove the attackers. Presumably the devastation was intended to make Americans reflect on the devastation that we have imposed upon others, and at least a few later did see similarities to the rubble from American bombing in Afghanistan. Many politicians and reporters worked overtime, by contrast, to portray the rubble as scenes of sacrifice by professional heroes who gave their lives to restore civilians to the status of innocent bystanders. What other reflections might the ruins stir in us even now?

7 For me, the collapse of the World Trade Center means rumination about how America, as a leading industrial nation, came to be reminded of the ephemeral quality of its hegemony in the world. The attacks brought home a concerted effort to defeat our power and influence, to end our reign. Two internationally recognized emblems of American strength, the Twin Towers, had been reduced to a pile of rubble. Monuments to American capitalism had been laid low. They had towered above lower Manhattan just as the United States has towered over other countries. Yet after the crashes, the strangely imposing presence of their ruins had become a sign of how America's unique mission, its exceptionalism as many believed it, was itself subject to erosion. As just another pile of rubble, it casts doubts on whether America will be so exceptional after all.

8 Yet as I hope to demonstrate, this painful (if necessary) lesson, if read allegorically, can be seen as an "origin." It can promote a new register of time recommended by Benjamin. It can become a radical break from a preceding history of American domination. It can ground a new beginning. This must be illuminated by insights as Ground Zero skylights kept the ruins visible even as they made ghost towers to commemorate our loss. Originary ruins could rescue Ground Zero from mere renovation, from its cooptation to combatting some "axis of evil," from its use in rekindling a self-centered creed of messianic exceptionalism for America. Rather than reinforce a mentality of arrogance and resentment that has made America despised by some, we can turn the rubble of Ground Zero into different senses of who we are and where we are going. ${ }^{2}$ 


\section{The Ruin as Allegory and Origin}

9 The writings of Walter Benjamin provide the theoretical framework for reading Ground Zero as allegory. It identifies deeper levels of political meaning amidst the towers' collapse. Indeed Benjamin's understanding of the ruin's semiotic compaction, its excess of meaning, can place Ground Zero in a broader context, drawing it into a larger reading of modernity's meanings and the various struggles that these meanings have spawned. It embeds the images of ruin in larger, ongoing narratives of culture. These are an archeplot for replaying the well-rehearsed themes of modernity's "progress" and America's superpower status against eviscerations painfully evident.

10 Allegory, of course, implies that the immediacies of material life are far more freighted with meanings than casual observation can register. It implies that a richness infuses the reality of commonplaces around us, that an unspoken yet significant set of narratives may be discerned in the literal worlds before us. Allegories "give us dynamic juxtapositions in a static frame," in the words of Robert Hariman, so that "the allegorical composition as a whole defeats the idea that there is one reality or one totalizing design."3 Allegories allude to depths hidden below the surfaces of reality. They invoke the surplus of interpretation that discerning critics can decipher. An allegory makes available an array of discourses, an overlapping of narratives whose apparent incongruity can itself be revealing. This explains why Benjamin saw his critical task as "blasting" the fragments out of their contexts, to unleash the occulted meanings found in "the storehouse of images yielded up to him and constructed in his shocking, healing writing." 4

11 According to Benjamin, two discourses that radically affect the western experience, both consciously and unconsciously, are theology and philosophy. For him, the poles of theological and socioeconomic experience intertwine to reveal the truth of modernity's impact. In ruins, he sought truths of modern times, when the United States has played a pivotal role. Improbable as it may seem, the intertwining of spiritual and Marxian axes enables for Benjamin the catastrophe of ruins to contain allegory. He explained that, together, these show our desire for something genuinely new in experience within contexts of modernity. Their incongruity provides a venue through which a beginning, an "origin" in Benjamin's language, might enter our experiences of modernity. ${ }^{5}$ Through contemplating ruins, reflecting on eviscerated realities of debris, we arrive at such origins within the narratives of modern life.

12 Benjamin's sense of allegory springs initially from an older reading of ruins grounded in theology. He located a capacity for allegory in theology's 
ability to endow the world with a sense of mission, a purposeful cohesion between our earthly status and God's divine plan. In several of writings, Benjamin makes use of the allegory of the ruin promulgated in seventeenth century Europe during the era of the Baroque. At that time, the ruin engaged dialectically what many thought to be an overabundance of theological meanings in the face of manifold religions and related cultures. These eroded the certainty and authority of any single religion. The result for many was malaise: an acedia from too much, not too little. Overabundances were evident in the proliferation of contending religions, the variety of creeds and customs, the conflicts among interpretations, the profusion of divine and temporal powers. An earlier Europe had lived with the virtual sovereignty of a few religions -- each plagued, of course, by internal strife. This later Europe felt that an explosion in beliefs and practices was destroying a former cohesion, offering a myriad of possibilities that fragmented a more unifying spiritual experience. Europe saw the standardized whole of Christendom broken into many competing pieces. Intellectually as well as spiritually, this meant overdetermination on occasion and cacophony overall. The world was too full of meanings. Having lost a unifying narrative, it now suffered a bewildering fragmentation.

13 The Baroque sensibility of ruin emphasizes a meaninglessness that too many possibilities deliver. Aimlessness and malaise make life into exhausting toil in the absence of coherence. In overdetermined realities, meaning appears arbitrary and erratic, as the world's connection to God seems lost or withheld. At the extreme, everyday life is as full of noise and commotion as it is devoid of intrinsic meaning. Connections among people wither with the onset of overabundance and despair. Recognition of this condition induces acedia, a weariness of life. Here the malaise of modernity and ruins ties to Benjamin's interest in Trauerspiel, German tragic drama, and the tragedies of Shakespeare. All respond to a plague of lost spiritual connections and a meaningless earthly existence where incessant toil and trouble -- "tomorrow and tomorrow and tomorrow" -contribute to a chronic, wearing sense of pain.

14 Benjamin's interest in this form of melancholia, from suffering a sort of spiritual exile, is evident in his 1916 essay "On Language as Such and On the Language of Man." In this text, he explains that the Ursprache, our "original" language, is "blissful" precisely because it lacks the arbitrariness that results from overdetermination. Ur-speech is Adamic language, the linguistic power that God gives to Adam to confer identity on the material world. It contains no arbitrary component, but reveals the unity between God's divine plan and the world as it exists. Before ruins and fragments, there is no overdetermination to induce the melancholy of acedia. Instead the originary language implies a unity of transcendent and immanent 
realms. "With the creative omnipotence of language it begins, and at the end of language, as it were, assimilates the created, names it. Language is therefore both the creative and the finished creation; it is word and nature."6

15 This blissful state between the world and its creator as expressed in Adamic language has its end, of course, in the Fall. The "ignorance" introduced into the world that ultimately drives our melancholic state of acedia has its inception with the Fall away from the edenic union that joins God's plan to the immediacy of the material world. What ensues, says Benjamin, is an overabundance of conventional languages, a prattle of meanings now localized hence arbitrary. A former connection to a defining origin has been lost; and an overdetermined, plethoric state of melancholia forms. Over-determination stems from over-naming. "Things have no proper names except in God. ... In the language of men, however, they are overnamed." Overnaming becomes "the linguistic being of melancholy."7

16 For Baroque sensibility, the world's material fullness replaces cohesive "bliss" with the "ignorance" and despair that result from fragmentation and repetition. Subjective interpretation unaligned with deeper meaning delivers a deadening effect, and the passage of time now severed from God is marked by an allegorical decay. Bits and pieces fall away, disperse, disintegrate. Chronology is the time of the Fall; and chronos unaided cannot recoup the redemption of cairos, an already fulfilled, purposeful time aligned with God's intent. In The Origin of German Tragic Drama, Benjamin explains how the rise of subjective interpretation, with its arbitrary ways and conventional idiosyncrasies, introduces for many people a sinister dimension. The world seems overwhelmed by randomness, and we shift from the immediacy of Ursprache toward allegory. "This knowledge, the triumph of subjectivity and the onset of an arbitrary rule over things, is the origin of all allegorical contemplation."8

17 Without theological underpinnings for realities of earthly transience, we learn especially from the "over-ripeness" of nature and the necessities of decay. The Baroque focus on decayed nature and architectural ruins points to allegorical aspects of this earthly life: "Thus, one might say, nature remained the great teacher for the writers of this period. However, nature was not seen by them in bud and bloom, but in the over-ripeness and decay of her creations."9 Baroque abstraction arises from dynamics of decay. Ruins suggest former structures; remains allude to the creaturely nature of our earthly existence, fated to decay. Even as decay demonstrates its "seal of the all-too-earthly," it takes on larger significance. "The allegorical has its existence in abstractions; as an abstraction, as a faculty of the spirit of language itself, it is at home in the Fall."10 As lived, material reality, chronological time reenacts the Fall from Ursprache into the Babel of a 
thousand languages. Human life becomes overdetermined, arbitrary, fated to decay.

18 Yet Benjamin insists on dialectics because these extremities of fallen nature can reveal deeper realities. In the melancholia of decaying fragmentation are traces of lost connections to withheld or hidden meanings. In fact, for Benjamin, a saturnine condition is always dialectical. The expression of sorrow evokes, if not revitalizes, what seems lost. In conventional languages and architectural ruins, the signs of rupture and fragmentation bear dialectically the imprimatur of a former cohesion that has now eroded.

19 That which mourns feels itself thoroughly known by the unknowable. To be named -- even when the namer is godlike and blissful -- perhaps always remains an intimation of mourning. But how much more melancholy it is to be named not from the one blessed paradisiacal language of names, but from the hundred languages of man, in which name has already withered, yet which, according to God's pronouncement, have knowledge of things. ${ }^{11}$

20 Hence Benjamin's vision of forlorn ruins reveals, not a despair of earthly decay, but an allegory of redemption. This is the inner logic of refuse. It turns around the meanings of the Trauerspiel as a dramatic form, where the expression of despair arises in relation to "mysterious pondering." With such pondering, decay transforms itself into subjectivity through allegory: "Subjectivity, like an angel falling into the depths, is brought back by allegories, and is held fast in heaven, in God, by ponderaciòn misteriosa."12 The traces of lost connections are to be found, then, in the most severed, the most fallen, existence. Images of ruins are allegorically charged with stories about the hidden meanings held, Benjamin intimates, in a collective unconscious. "In the ruins of great buildings the idea of the plan speaks more impressively than in lesser buildings, however well preserved they are. ... Others may shine resplendently as on the first day; this form preserves the image of beauty to the very last."13

21 This "beauty" is precisely that of a redeemed reality that might result once the wishes of the collective unconscious are given expression. At least in his later work, Benjamin does not follow the Christian ethos of the Baroque in making redemption turn on messianic intervention. Instead his argument for a redeemed reality that points to our stored-away wishes invokes the other source of his thought: the Marxian pole focused on class relations and distributive justice. This draws us much closer to home, to an analysis of our socioeconomic realities, set against the backdrop of modern "progress."

22 The hollowed out, fragmented realities that most concerned Benjamin were not those of seventeenth-century ruins but of his own epoch in the 
twentieth century. The Baroque theory of allegorical ruins is an armature for his analysis of present capitalist relations. Their dynamics parallel the Baroque emblematics that Benjamin finds in German tragic drama. The allegory of ruins becomes a lens for reading injustices and inhumanities of modern socioeconomic relations. It evokes the vacuity of a culture that relies on commodities to mediate human relations. As a Marxist, Benjamin treats commodity fetishism as the underside of modernity. Admittedly this is but one, quite negative, reading of modernity. Others stress that modernity cannot be understood apart from its success and that the darker side of capitalism cannot meaningfully be severed from the progress it has delivered.14 Yet commodity fetishism is essential to Benjamin's allegory: the horrors of consumer society are the modern horrors apparent in his allegory of redemption from ruins.

23 In capitalism, Marx argues, the value of goods in circulation has been severed from the labor that went into them. Consequently their prices become arbitrarily, assigned according to "metaphysical subtleties." "Hence exchange-value appears to be something accidental and purely relative," writes Marx in the first volume of Capital. As a result, "an intrinsic value, i.e., an exchange-value that is inseparably connected with, inherent in commodities, seems a contradiction in terms."15 For Benjamin, this tenet provides a clear parallel between Baroque ruins and capitalist relations. Like Baudelaire, Benjamin sees allegorical dimensions in the flux of modernity. "The 'metaphysical subtleties' in which the commodity delights, according to Marx . . . are, above all, the subtleties of price formation. How the price of goods in each case is arrived at can never quite be foreseen. ... It is exactly the same with the object in its allegorical existence."16 In capitalism, market relations alone dictate how much commodities are valued; neither the material properties nor the labor time for production can fix an inherent, unchanging value of an item for sale. J ust as ruins register how the Fall severs us from cairological time and empty modern experiences of meaning, so commodities become "hollowed out," with prices that seem to rise and fall haphazardly -- helping to empty our surroundings and ourselves of meaning. To ponder the husks that remain, however, can be to reveal such stories of decline and decay -helping to restore significance and redeem modernity.

24 The commodity fetishism that permeates capitalist culture necessarily spurs production of an abundance of items for purchase. Their values fluctuate continually. Even the manner of their presentation -- with prices next to them in store windows or magazine pages -- announces that commodities can have no intrinsic worth. Displays, advertisements, and other venues of capitalism provide a visual panorama of values in flux. Although this promises contentment and a sense of completion, it shows commodities as hollow even as it promotes them as the medium for human 
relations. As Benjamin says in The Arcades Project, "The culture of the commodity presses such fetishism into its service."17

25 So commodities parallel ruins. Both are signs of forlorn realities left to the mercies of conventional, arbitrary meaning. Even as commodities promise fulfillment, these fragments of modernity become items for sale with fluctuating prices that, like proliferating languages, can regenerate the allegory of loss available in Baroque ruins. Ground Zero makes the identification complete, giving us commodities as ruins and ruins as commodities. The Twin Towers lodged the capitalist engine of modernity, and their ruins are its fragments. For Benjamin, capitalism shares in the overarching semiology of the Baroque. In the ruins of the World Trade Center are signs of modern progress and dehumanization, modern liberation and exploitation, even modern abstraction and fragmentation and -- possibly -- redemption. Benjamin's theoretical poles -- one theological, the other Marxian -- meet to explain our need for something genuinely new to spring from remnants. Stored in our collective unconscious, he suggests, there resides a longing for an "origin," a break with the past that can deliver a more just social order. Benjamin's allegory of ruin, when brought to bear on capitalist relations and remains, can help unveil our desire for a new society that lies buried beneath capitalism's incessant showcasing of something "new and different" or "new and improved."

\section{J eztzeit: "The Idea of the Plan" Contained in Ground Zero}

26 For Benjamin, this is a new register of time, J eztzeit. It would deemphasize commodity fetishism. In positing such an origin, Benjamin is careful not to restate capitalism's totalizing discourse in an idyll of community. The "mysterious pondering" of ruins is dialectical, and he does not expect the origin to recreate edenic wholeness. If it did, it would replay the deceitful promises of capitalism. Yet ruins do reveal a collective longing for a new beginning, severing us from the painful, fragmentary moments of chronos and moving toward a more fulfilled time of cairos, marked by greater justice and better order.

27 An oppositional reading of the World Trade Center may favor its later, crumbled remains over its earlier, staunch towers. This is because, in their ruinous state after $9 / 11$, "the idea of the plan speaks more impressively than in lesser buildings." 18 The destruction and death have been terrible, but we may redeem them mainly by pondering what remains. I would not argue that our longing for an "origin" whence we can behold "the idea of the plan" will ever reveal the contents of a collective American unconscious 
that would lead everybody to the gleaming city on the hill. But I would expect it to reveal the desire at least for a new intellectual insight. This origin would rethink America's identity as the premier superpower. It would embrace a new understanding of humbler missions for America. To indicate that the seemingly ruinous passage from modern relations into cairological time must be primarily intellectual, Benjamin quotes from Le Voyage, a poem by Baudelaire. It says that we must journey "deep into the unknown" in order to begin again. In the rubble, in the ruins we have not known, our reflections can originate. "Death, old admiral, up anchor now . .. Deep in the Unknown to find the new!"19

28 Benjamin sees in commodities and ruins the emptiness of modern progress. Only when we abandon America's false, self-serving claims to progress can we begin to think differently about what the country's towering economic success and ensuing military strength have meant to those whom it has harmed. Would we then declare a global "war on terrorism" or target an "axis of evil?" Pondering the ruins of Ground Zero, we would break with America's self-image from the twentieth century, and we would rethink the international roles of the United States. Nothing can divest the site of its tragic dimensions and political associations. Yet in the allegory of WTC rubble, we might ground perspectives that depart from the historical paths that have ended there.

29 "The spirit of allegory," Benjamin maintains, "is conceived from the outset as a ruin, a fragment." 20 From its inception, America has been infused with the language of edenic promises and fulfilled hopes. For many, it has been the NewJ erusalem, capable of fusing chronological and cairological time. It has been a cornucopia of goods become commodities. Ground Zero is the place where the issues of these towering ambitions have become plain. To ponder its ruins is to consider why some people have thought America so evil that it must be brought low. ${ }^{21}$ To reflect on its rubble is to reconsider the American plan for fusing chronological and cariological time. "The purpose of [the Puritan] jeremiads was to direct an imperiled people of God toward the fulfillment of their destiny," says Sacvan Bercovitch in The American J eremiad, "to guide them individually toward salvation, and collectively toward the American city of God."22 Yet the gleaming city on the hill, "from Israel in Canaan to New Israel in America," is not the origin suggested by Ground Zero. ${ }^{23}$ The newness of J eztzeit apparent in the WTC remains can provide fulfillment because it resists totalizing schemes like Twin Towers capitalism or Puritan theology.

30 The origin found here at Ground Zero would awaken us to how sinister, how ominous, how perverse American culture appears to some. To much of the world, and surely to Islamic fundamentalists, the vision of the WTC's two towers rising above the lower Manhattan skyline formerly represented 
nothing other than the threat of modernity to infiltrate every terrain of culture, ideology, and geopolitics. The Twin Towers stood for American strength and influence, our hegemonic privilege, our pervasive popular culture, our secularism and commitment to civil liberties. They stood for everything new, modern, even postmodern: the Americanization of the world with Coke, hamburgers, sex, and loud music. The magnitude of American power could be seen in the commanding presence of the World Trade Center. Its architectural immensity paid daily homage to the global reach of capitalism. In a sense, the WTC was Americanization, even modernization. It was "the new" in the pejorative sense, an effort to embody progress. Yet once the two towers were reduced to rubble, the horrific images of Ground Zero cast a pall over both the enemies and the advocates of this vision. Does it induce unwarranted envy? Does it provoke justifiable outrage? Does it deliver substantial fulfillment? The ruins' surplus of meaning raises questions about America, capitalism, and modernization.

31 If the dialectics of rubble at Ground Zero contribute to a collective rethinking of who we are, they can help us make sense of the horror on that hollowed, hallowed site. If they teach us anew about lost values, the ruins of September 11 can be said to have marked an origin. If they restore a capacity of self-criticism for Americans, they can start to redeem the destruction. And if they re-story our culture of manifest destiny, they can begin to redirect our everyday politics.

32 In response to iconic images in America, including the ruins of Ground Zero, Hariman argues that the schematic approach of allegory to an overabundance of meanings is especially useful during times of rapid, wrenching change. When one narrative or archeplot gives way to another - pagan to Christian, Baroque to modern, modern to postmodern -- an allegorical ability to see interpretive surplus in literal realities can help us to formulate an emerging vision for our cultures. It "activates a mode of consciousness that is ideally suited to managing contemporary paradoxes of cultural transformation."24 It helps "equip people to make sense of their lives in a period of accelerated cultural change characterized by pluralism, fragmentation, and inevitably provisional forms of community."25 To allegorize the ruins of Ground Zero is to insist not only that Americans can make sense of their lives after September 11 but that they can make new and better lives by pondering the fragments remaining. With Benjamin and Hariman, I suggest that allegory may be particularly suited to modern democracies in transition, societies moving away from outdated cultural narratives. Pondering the ruins of Ground Zero can take us beyond the capitalist ideology of the Twin Towers and the American adherence to myths of exceptionalism. It can cultivate an intellectual openness that 
allows us to build "more egalitarian, caring, creative communities."26

33 The upper echelons of American government are unlikely to respond to September 11 in this way. The recent war with Iraq implies the obverse of what Benjamin -- or probably even Shakespeare -- might like to see. Still the reflection on ruins is an undertaking available to us all. The rubble at Ground Zero has been hastily, almost heroically, cleared; and plans are progressing for building something new on the site. Yet the images of Ground Zero endure, circulating with telling intensity on television and the Internet. Images of immense piles of debris and deep holes of devastation are unlikely to recede from our memories for many years. If we ruminate long enough on their meanings in the contexts of 9/11, their deeper, allegorical significance may well take root -- at least among people who dare to rethink America's mission for a more humane role in world affairs.

(C) Mary Caputi, 2003.

\section{Notes}

1 This reading of Walter Benjamin's theory of the ruin, allegory, and redemption relies especially on Susan Buck-Morss, The Dialectics of Seeing: Walter Benjamin and the Arcades Project, Cambridge, MA, MIT Press, 1989; Max Pensky, Melancholy Dialectics: Walter Benjamin and the Play of Mourning, Amherst, University of Massachusetts Press, 1993; Kia Lindroos, Now-Time/Image-Space: Temporalization of Politics in Walter Benjamin's Philosophy of History and Art, Jyväskylä, Finland, SoPhi, 1998; Pierre Missac, Walter Benjamin's Passages, Shierry Weber Nicholsen, tr., Cambridge, MA, MIT Press, 1995.

2 The post-9/11 resurgence of a Cold War mentality is unfortunate, not only for all that it imposes strategically and symbolically, but also for all that it misses. Rather than capitalize on a moment when America might rethink its orientation toward the Muslim world, the current administration has enlarged the ideological differences that separate Us from Them in a rhetoric that fails to encourage introspection. "Declaring a world as new is . . . a distraction from some unresolved problems," writes Sheldon S. Wolin in "Brave New World," Theory and Event, 5, 4, 2002, p. 1. The opportunity is to take our post-September 11 situation to experience a "teachable moment," as one of my colleagues calls it. The need is to recognize what America's status as an affluent nation long supportive of Israel might mean to Muslims. Using McCarthyite language that overgeneralizes both, the Bush administration has chosen instead to caricature the differences between western democracies and the cultures of Islam. The "road map" to a Palestinian state suggests a shift in outlook and policy, yet too much of the official response to the terrorist attacks turns away 
from introspection and relies instead on a hackneyed vision reminiscent of 1950s hysteria. As David Campbell observes, "What we have, then, is the war on terrorism morphing into a rerun of the Cold War." See "Time Is Broken: The Return of the Past in Response to September 11," Theory and Event, 5, 4, 2002, p. 6.

3 Robert Hariman, "Allegory and Democratic Public Culture in the Postmodern Era," Philosophy and Rhetoric, 35, 4, 2002, pp. 268-273.

4 Pensky, Melancholy Dialectics, p. 16.

5 Benjamin's sense of ruinous origins contrasts to the West's metaphysical quest for absolute grounds, certain origins, and guaranteed foundations. Comparable conceptions of beginnings appear in Hannah Arendt, On Revolution, New York, Viking Press, 1963 and Edward Said, Beginnings, New York, Basic Books, 1975.

6 Walter Benjamin, "On Language as Such and On the Languages of Man," Edmund J ephcott, tr., Walter Benjamin, Selected Writings, Volume I: 1913-1926, Marcus Bullock and Michael W. J ennings, eds., Cambridge, MA, Harvard University Press, 1997, p. 68.

$7 \quad$ Ibid., p. 73.

8 Benjamin, The Origins of German Tragic Drama, J ohn Osborne, tr., London, Verso, 1988, p. 233.

9 Ibid., p. 179.

$10 \quad$ Ibid., p. 234.

11 Benjamin, “On Language as Such,” p. 73.

12 Ibid., p. 235.

13 Ibid.

14 Marshall Berman explains how the modern era is "capable of the most spectacular growth," capable of the great strides and new freedoms, but also "capable of appalling waste and devastation": All That Is Solid Melts Into Air: The Experience of Modernity, New York, Penguin Books, p. 19.

15 Karl Marx, "Capital, Volume I," The Marx-Engels Reader, Robert C. Tucker, ed., New York, Norton, 2nd ed., 1978, p. 304.

16 Benjamin, The Arcades Project, Howard Eiland and Kevin McLaughlin, 
trs., Cambridge, MA, Harvard University Press, 1999, pp. 368-369.

17 Ibid., p. 8.

18 Benjamin, "The Origins of German Tragic Drama," p. 235.

19 Quoted in The Arcades Project, p. 11.

20 Benjamin, The Origin of German Tragic Drama, p. 235.

21 For an in-depth discussion of America's prophetic mission and its ability to reconcile chronos and cairos, see Sacvan Bercovtich, The American Jeremiad, Madison, University of Wisconsin Press, 1978. To juxtapose this to Benjamin's understanding of time's two registers, see Lindroos, Now-Time/ Image-Space.

22 Bercovitch, The American J eremiad, p. 9.

23 Ibid., p. 14.

24 Hariman, "Allegory and Public Culture in the Postmodern Era," p. 289.

25 Ibid., p. 288.

26 Ibid., p. 288. 